\title{
Institusionalisasi Proses Mediasi dalam Sistem Peradilan di Indonesia
}

\author{
Sri Wardah
}

\begin{abstract}
The mediation process of internalization in the judicature system which it is expected to strengthen and maximize the function of judicature Institution forming in judicial conflict solution and the function of the law strengthen and the justice managed through PERMA, in order that it can be improved effectively in the form of legislation.
\end{abstract}

\section{Pendahuluan}

Mediasi sebagai salah satu mekanisme penyelesaian sengketa alternatif di luar pengadilan sudah lama dipakai dalam berbagai kasus seperti kasus bisnis, lingkungan hidup, perburuhan, pertanahan, perumahan, dan sengketa konsumen. Mediasi merupakan perwujudan tuntutan masyarakat atas penyelesaian sengketa yang cepat, efektif, dan efisien.

Institusionalisasi mediasi sebagai mekanisme penyelesaian sengketa yang in- tegral dalam proses peradilan di Indonesia relatif masih muda usia yaitu setelah terbitnya Peraturan Mahkamah Agung (PERMA) Nomor 2 Tahun 2003, tanggal 11 September 2003.' Kebutuhan peraturan ini sangat signifikan, mengingat kondisi kongesti (tunggakan pérkara) di Mahkamah Agung sudah sedemikian memprihatinkan, sedang kemampuan Mahkamah Agung untuk menyelesaikannya tidak sebanding dengan jumlah perkara yang masuk setiap tahunnya. ${ }^{2}$

' Sebelumnya telah dikeluarkan Surat Edaran Mahkamah Agung (SEMA) Nomor 1 Tahun 2002 tentang Pemberdayaan Upaya Perdamainan berdasarkan Pasal 130 HIR/154 Rbg. sebagai upaya Mahkamah Agung untuk mengurangi menumpuknya perkara serta demi mewujudkan peradilan sederhana, cepat dan biaya ringan.

2 Lahirnya lembaga mediasi melaluj Peraturan Mahkamah Agung ini disambut positif oleh berbagai pihak, karena melalui mediasi di pengadilan, tidak hanya dapat mengurangi penumpukan perkara tetapi juga yang terpenting adalah tersedianya alat bagi masyarakat untuk menyelesaikan sengketanya tanpa harus berperkara di pengadilan (itigasi) yang umumnya berlangsung lama dan mahal. Masyarakat atau justisiabel sangat berkepentingan akan penyelesaian sengketa yang sederhana, efisien baik dari segi waktu maupun biaya. Pemakaian lembaga mediasi pengadilan ini lebih menguntungkan para pihak karena sengketa dapat diselesaikan 
Kenyataannya, sebagian besar perkara yang masuk di Mahkamah Agung adalah perkara perdata.

Sebagai tindak lanjut PERMA Nomor 2 Tahun 2003 tersebut Mahkamah Agung bekerja sama dengan Indonesian Institute for Conflict Transformation (IICT) menetapkan Pengadilan Negeri Jakarta Pusat, Pengadilan Negeri Surabaya, Pengadilan Negeri Padang, dan Pengadilan Negeri Bengkalis sebagai proyek percontohan mediasi di pengadilan selama 1 (satu) tahun.

Meskipun penyelesaian sengketa melalui mediasi pengadilan ini mengandung berbagai keuntungan tetapi sebenamya juga merupakan mekanisme yang rentan, maksudnya kemungkinan untuk gagal juga sangat besar. ${ }^{3}$ Untuk mengantisapasinya memerlukan prasyarat yang harus dipenuhi misalnya kepercayaan, kesediaan atau kerelaan untuk melepaskan sebagian hak dari masing-masing pihak yang bersengketa.

\section{Alternative Dispute Resolution (ADR) dan Perkembangannya}

Alternative Dispute Resolution (ADR) merupakan eksperimen untuk mencari modelmodel baru dalam penyelesaian segketa, penerapan baru terhadap metode lama, forum baru bagi penyelesaian șengketa, dan penekanan yang berbeda dalam pendidikan hukum. ${ }^{4}$ Dari batasan tersebut ADR merupakan mekanisme penyelesaian sengketa di luar pengadilan yang didasarkan atas kesepakatan para pihak. Sebagai konsekuensi kesepakatan para pihak ADR bersifat sukarela dan tidak dapat dipaksakan oleh salah satu pihat ataupun pihak lain. Meskipun demikian sebagai bentuk perjanjian

dengan adil menurut kehendak pihak-pihak yang bersengketa, cepat, sederhana karena tifak banyak formalitas yang diperlukan dan biaya tidak mahal. Prosedur litigasi ditempuh sebagai upaya terakhir jika mediasi tidak membuahkan hasil. Dibandingkan dengan mediasi di luar pengadilan, mediasi dalam proses penyelesaian sengketa di pengadilan lebih memiliki nilai lebih (jika berhasil) antara lain karena executable sehingga memiliki kewibawaan. Institusionalisasi mekanisme mediasi dalam proses penyelesaian sengketa di pengadilan juga dapat mendorong upaya damai sebagai solusi yang utama oleh para pihak yang bertikai.

${ }^{3}$ Beberapa kasus mediasi setelah lahirnya Perma mengalami kegagalan antara lain di PN Jakarta Selatan, mediasi antara Takashu Masaharu (penggugat) dengan PT Coca Cola Amatil, Coca Cola Bottling, Coca Cola Distributor (para tergugat). Di Pengadilan Negeri Jakarta Pusat, proses mediasi perkara gugatan 13 partai politik terhadap Presiden, Sekretaris Negara, Kepala Badan Pertanahan Nasional, Gubernur DKI Jakarta dan tiga parpol besar (Golkar, PDIP dan PPP) atas penguasaan aset negara oleh tiga parpol besar bulan Februari 2004 yang lalu juga mengalami kebuntuari atau kegagalan karena tidak tecapai kesepakatan diantara para pihak yang bersengketa. Demikian juga kasus antara Abdurrahman Wahid (penggugat) dengan Komisi Pemilihan Umum, Pengurus Besar Ikatan Dokter Indonesia dan Departemen Kesehatan (para tergugat), kasus PT Dharma Sakti Sejahtera Tbk. (Penggugat) melawan PT Asuransi Jiwa Manulife (tergugat), nampaknya sulit mencapai kompromi. Lihat http://www.hukumonline.com/brt/cr-1/4Juni2004, http://www.Kompas.com/brt dwal 16-3-2004; http://www.kompas.com/brt/ma/10-6-2004/13:45; dan hittp://www.hukumonline.com/leo/gie,23-62004/20:15.

4 Gorge Applebey, An Overview of Altemative Dispute Resolution, dalam C. Samson \& J. McBriede, Altemative Dispute Resolution (Les Presses de J'Universite Laval Sainte-Foy, 1993), him 590. 
(alternatif , penyelesaian sengketa) kesepakatan yang telah dicapai harus ditaati. Seberapa jauh kesepakatan untuk menyelesaikan sengketa di luar pengadilan itu mengikat dalam sistem hukum positif yang berlaku, tidak ada persamaan yang berlaku secara universal untuk semua aturan hukum yang berlaku. ${ }^{5}$ Di Indonesia instrumen altematif penyelesaian sengketa (ADR)-secara garis besar dapat diklasifikasikan ke dalam konsultasi, negosiasi, mediasi, konsiliasi, atau penilaian ahli. ${ }^{6}$

Di negara-negara yang sudah maju (developed countries) maupun negara negara industri baru (new industrialized countries) telah menempatkan ADR sebagai the first resort dan pengadilan sebagai the last resort. ${ }^{7}$ Sementara realitas masyarakat Indonesia masih menempatkan pengadilan sebagai the first and the last resort. Pengadilan merupakan satu-satunya. lembaga yang sah dan resmi menyelesaikan segala sengketa yang timbul dalam masyarakat. Yahya Harahap mengemukakan, bahwa setiap penyelesaian harus menurut tata cara formal yang diatur dalam hukum acara serta memberi hak kepada para pihak untuk menggunakan upaya hukum secara instansional, menyebabkan kecenderungan ke arah sistem litigasi yang sangat formalistik, teknis dan biaya mahal. Citra peradilan sebagai the first and the last resort akan makin merosot. ${ }^{8}$

Jika dilihat latar belakang pendayagunaan Alternatif Penyelesaian Sengketa di Amerika, negara yang pértama kali memunculkan istilah ADR dan sebagai representasi negara industri dan ekonomi maju dengan negara-negara yang menganut akar budaya non konfrontatif yang pada umumnya dimiliki oleh negara berkembang, terdapat sedikit perbedaan. Latar belakang pendayagunaan ADR di negara maju disebabkan ketidakpuasan terhadap sistem peradilan, sedangkan negara-negara yang menganut akar budaya non konfrontatif adalah melestarikan budaya non adversial menuju masyarakat yang lebih stabil (social stability) sekaligus akses keadilan (proses pemeriksaan yang cepat, murah, dan sederhana). Sistem pengadilan dianggap merupakan institusi yang tidak memenuhi kebutuhan di atas. ${ }^{9}$

Bentuk-bentuk ADR yang digunakan di beberapa negara antara lain di Amerika Serikat populer dan digemari mekanisme arbitrase, compulsory arbitrase system, mediasi, konsiliasi dan minitrial, summary juri trial, dan Settlement Conference. Di Jepang terdapat The Japan Coomercial Arbitration Assosiation (JCAA), Labour Commicion; The Enviromental Disputes Coordination Commision, Arbitration Centre of Local Bar Assosiation, The Centre of Hedling Traffic Acident Disputes. Lembaga-

${ }^{5}$ Gunawan Wijaya, Altematif Penyelesaian Sengketa (Jakarta: Raja Grafindo Persada, 2001), hlm 2

${ }^{6}$ Lihat Pasal 1 angka 10 Undang-Undang Nomor 30 Tahun 1999 tentang Arbitrase dan Alternatif Penyelesaian Sengketa.

7 Joni Emirzon, Altematif Penyelesaian Sengketa di luar Pengadilan, (Jakarta: SUN, 2000), hlm 5.

${ }^{8}$ M. Yahya Harahap, Beberapa Tinjauan Mengenai Sistem Peradilan dan Penyelesaian Sengketa (Bandung: Citra Aditya Bakti, 1997), hlm 280.

${ }^{9}$ Mas Achmad Santosa, Mekanisme Penyelesaian Sengketa Lingkungan Secara Kooperatif (Alternative Dispute Resolustion) (Jakarta: Indonesian Centre for Enviromental Law, 1995), hlm 1. 
lembaga ini umumnya prosesnya mencirikan penggunaan antara mekanisme mediasi, konsiliasi dan arbitrase. Hongkong populer dengan arbitrase, mediasi dan ajudikasi (khusus dalam sengketa dibidang konstruksi). Singapura memiliki Court Mediation Centre dan pelembagaan ADR dilaksanakan di Subordinate Court Singapura.

Institusionalisasi alternatif penyelesaian sengketa bagi bangsa Indonesia sebenarnya sudah sejak lama mengenal pola-pola penyelesaian secara tradisional yaitu yang dilakukan melalui peradilan adat ataupun peradilan desa yang mempunyai dasar filosofis musyawarah mufakat dalam penyelesaian perkaranya. Terutama dalam masyarakat tradisional nilai-nilai konfrontatif dan kooperatif dalam penyelesaian konflik atau sengketa dapat mengemuka. Dalam masyarakat Batak yang relatif lebih memiliki budaya litigius, masih mengandalkan forum runggun adat yang pada intinya adalah penyelesaian sengketa secara musyawarah dan kekeluargaan. Masyarakat Minangkabau dikenal dengan lembaga hakim perdamaian Minangkabau yang secara umum peranannya sebagai mediator dan konsiliator. Demikian juga halnya di Jawa, konsep pembuatan keputusan dalam pertemuan desa tidak didasarkan pada suara mayoritas, tetapi dibuat oleh keseluruhan yang hadir sebagai satu kesatuan. Mayoritas maupun minoritas dapat membatasi pendapat mereka sehingga dapat saling sejalan.
Konsep musyawarah demikian itu sejalan dengan corak negosiasi modern yang dikenal dengan teknik interest based bargaining, yang merupakan corak atau teknik negosiasi modern yang popular dan diterapkan di berbagai negara. ${ }^{10}$ Sejak masa pemerintahan kolonial Belanda sudah terdapat institusi alternatif penyelesaian sengketa di luar pengadilan yaitu yang diatur dalam Pasal 615-651 Reglement op de Burgelijke Rechtsvordering (RV) yang berupa prosedur arbitrase atau perwasitan yang dipakai sebagai landasan hukum bagi upaya penyelesaian sengketa khususnya sengketa dagang. Sejak tahun 1977 telah didirikan Badan Arbitrase Nasional Indonesia oleh Kamar Dagang dan Industri Indonesia (KADIN) yang bersifat otonom dan independen serta telah mengalami perbaikan pada tanggal 3 Desember 1980. Badan ini berfungsi untuk menyelesaikan sengketa-sengketa perdata yang timbul mengenai soal-soal perdagangan, industri dan keuangan baik dalam skala nasional maupun internasional.

Paralel dengan perkembangan dunia bisnis, di negara kita fenomena penggunaan mekanisme ADR juga semakin menguat. ADR dipandang sebagai bagian integral dari bisnis itu sendiri dan dianggap cocok untuk dunia bisnis karena penyelesaiannya cepat dan biaya murah. Meningkatnya aktivitas dan transaksi bisnis tanpa dijajari dengan mekanisme penyelesaian yang favourable yakni. ADR - di antara mereka yang terlibat dalam lingkaran bisnis adalah tidak mungkin."

\footnotetext{
${ }^{10}$ Lihat Rachmadi Usman, Pilihan Penyelesaian Sengketa diluar Pengadilan (Bandung: Citra Aditya Bakti, 2003), hlm 32.

"Nandang Sutrisna, "Penyelesaian Sengketa Bisnis di luar Pengadilan: ADR sebagai Pilihan", makalah diskusi Fakultas Hukum Universitas Islam Indonesia (Yogyakarta).
} 
Meskipun ADR dipandang sebagai bagian integral dari bisnis itu sendiri dan dianggap cocok untuk dunia bisnis karena penyelesaiannya cepat dan biaya murah, namun menurut Joni Emeron, ADR hanya dapat bertumpu di atas etika bisnis yang tinggi. ${ }^{12}$ Tanpa landasan tersebut ADR tidak mungkin berperan karena bagaimanapun juga ADR bukan merupakan badan peradilan resmi (ordinary court) yang memiliki wewenang memaksa. ADR hanya lembaga swadaya masyarakat yang berkedudukan sebagai "extra judicial". ${ }^{13}$

Kecenderungan masyarakat internasional untuk menggunakan ADR menurut Mas Achmad Santosa adalah didasarkan atas beberapa faktor keunggulan sebagai berikut:

1. Faktor ekonomis. ADR memiliki kemampuan sebagai sarana penyelesaian sengketa yang lebih ekonomis, baik dari sudut pandang biaya maupun waktu.

2. Faktor luasnya ruang lingkup permasalahan yang dibahas. ADR mempunyai kemampuan untuk membahas atau agenda permasalahan secara luas dan konprehensif. Hal ini terjadi karena aturan permainan dikembangkan serta di tentukan oleh para piiak sesuai dengan kepentingan dan kebutuhan para pihak yang bersengketa.
3. Faktor Pembinaan hubungan baik para pihak. ADR yang mengandalkan cara-cara penyelesaian yang kooperatif sangat cocok bagi mereka yang menekankan pentingnya pembinaan hubungan baik antar manusia baik yang sedang berlangsung maupun yang akan datang.

4. Faktor proses. ADR yang lebih fleksibel dibandingkan dengan beracara di pengadilan lebih memiliki kemampuan untuk menghasilkan kesepakatan yang mencerminkan kepentingan dan kebutuhan para pihak (pareto optimal atau win-win solution $).{ }^{14}$

Mengingat Indonesia telah turut serta secara aktif, baik dalam lingkup regional dalam mendukung terwujudnya AFTA (ASEAN Free Trade Area) dan APEC (Asia Pasific Economic Cooperation) maupun dalam lingkup global dengan telah dikeluarkannya Undang-Undang Nomor 7 Tahun 1994 tentang Pengesahan Agreement of Establishing Word Trade Organization (WTO) mau tidak mau harus diciptakan suatu mekanisme sengketa yang lebih efektif dan efisien. Dengan demikian alternatif penyelesaian sengketa khusus bisnis merupakan kebutuhan yang mendesak mengingat intensitas hubungan bisnis dan investasi makin ramai dan konflik atau sengketa bisnis juga semakin sering terjadi.

\section{Joni Emeron, op. cit., h/m 14.}

${ }^{13}$ Yahya Harahap, "Alternative Dispute Resolution (ADR), Merupakan Jawaban Penyelesaian Sengketa Perdagangan Internasional Masa Depan", Makalah pada Temu IImiah Nasionall SMAHII Implikasi Liberalisasi Perdadagan Intemasional terhadap Pembangunan Hukum Nasionaf', (1995), hlm 27.

${ }^{14}$ Mas Ahmad Santosa, "Alaterntive Dispute Resolution (ADR) di Bidang Lingkungan Hidup", disampaikan pada Forum Dialog tentang Altemative Dispute Resolution (ADR), (Jakarta: Tim Pakar Hukum Departemen Kehakiman dan The Asia Fondation, Departemen Kehakiman dan Asia Fondation, 1995), him 1 dan Mas Achmad Santosa, Pendayagunaan Mekanisme Altematif Penyelesaian Sengketa (MAPS) di Bidang Lingkungan di Indonesia (Jakarta: Indonesian Centre for Environmental Law, 1995), hlm 1-2. 
Demikian juga tuntutan perkembangan dibidang lainnnya sebagai dampak teknologi ataupu ekonomi global, seperti masalah perburuhan atau ketenagakerjaan, lingkungan, perpajakan dan sebagainya. Berbagai peraturan perundangan yang melegitimasi Arbitrase dan bentuk bentuk.

Altematif Penyelesaian Sengketa sebagai institusi yang berfungsi menyelesaikan sengketa di luar pengadilan antara lain dapat ditemukan dalam Undang-Undang Nomor 23 Tahun 1997 tentang Pengelolaan Lingkungan Hidup, Undang-Undang Nomor 32 Tahun 1997 tentang Pedagangan Berjangka Komoditi, Undang-Undang Nomor 8 Tahun 1998 tentang Perlindungan Konsumen, Undang-Undang Nomor 18 Tahun 1999 tentang Jasa Konstruksi, Undang-Undang Nomor 30 Tahun 1999 tentang Arbitrase dan Alternatif Penyelesaian Sengketa, UndangUndang Nomor 14 Tahun 2001 tentang Paten, Undang-Undang Nomor 15 Tahun 2001 tentang Merek, dan Undang-Undang Nomor 13 Tahun 2003 tentang Ketenagakerjaan. Dengan adanya peraturan perundanganundangan tersebut, maka peluang untuk mendayagunakan berbagai bentuk penyelesáian sengketa di luar pengadilan (khususnya penggunaan lembaga mediasi) semakin besar. Demikian juga jangkauan cakupan persoalan dalam kehidupan masyarakat yang dapat diselesaikan melalui kelembagaan tersebut.

\section{Mediasi dalam Praktek di Indonesia}

Undang Undang Nomọ 30 Tahun 1999 tentang Arbitrase dan Alternatif Penyelesaian Sengketa tidak memberikan pengertian yang jelas tentang berbagai bentuk penyelesaian sengketa termasuk mediasi, kecuali arbitrase. Bahkan proses atau mekanisme masingmasing bentuk lembaganya juga tidak diatur. Sebagian besar hanya mengatur secara lengkap tentang proses arbitrase. Oleh karena itu sebenarnya lebih tepat jika undang-undang tersebut disebut sebagai Undang Undang Arbitrase.

Pasal 6 ayat (3) Undang Undang Nomor 30 Tahun 1999 tentang Arbitrase dan Alternatif Penyelesaian Sengketa hanya menyebutkan bahwa dalam hal sengketa atau beda pendapat sebagaimana dimaksud dalam ayat (2) tidak dapat diselesaikan, maka atas kesepakatan tertulis para pihak, sengketa atau beda pendapat diselesaikan melalui bantuan seorang atau lebih penasehat ahli maupun melalui seorang mediator. Pada intinya pasal ini memberi peluang kepada masyarakat untuk menyelesaikan sengketanya melalui mediasi.

Kamus hukum Indonesia memberi batasan mediasi sebagai proses pengikutsertaan pihak ketiga dalam penyelesaian suatu perselisihan sebagai penasehat, ${ }^{15}$ atau merupakan salah satu altematif penyelesaian sengketa di luar pengadilan dengan menggunakan jasa seseorang mediator atau penengah; sama seperti konsiliasi. ${ }^{16}$

${ }^{15}$ Pusat Pembinaan dan Pengembangan Bahasa, Kamus Besar Bahasa Indonesia (Jakarta: Departemen Pendidikan dan Kebudayaan), hlm 569.

${ }^{18}$ Elly Erawati dan J.S Badudu, Kamus Hukum Ekonomi ELIPS (Jakarta: ELIPs Project, 1997), him 111. 
Dalam literature kita temukan beberapà pengertian mediasi àntara lain:

1. Mediasi adalah proses negosiasi pemecahan masalah di mana pihak luar yang tidak memihak (impartial) dän nietral bekerja dengan pihak yang bersengketa untuk membantu mereka memperoleh kesepakatan perjanjian "dengan memuaskan. Berbeda dengan hakim atau arbiter, "mediator -tidak mempunyai wewenang untuk memutuskan sengketa antara pära pihak. Namun dalam hal ini para pihak 'menguasakan kepada'mediator untuk membantu' . 'mereka menyelesaikan persoalan-persoalan di antara méreka. Asumsinya bahwa pihak ketiga akàn mampu mengubah kekuatan dan dinamika sosial hubungan konflik dengan cara mempengaruhi kepercayaan dan tingkah laku pribadi para pihak dengan memberikan pengetahiuan atau informasi atau dengan menggunakan proses negosiasi yang lebih efektif dan dengan demikian membantu para peserta untúk - menyelesàikan pérsöalanpersoalan yang dipersengketakan. ${ }^{17}$.

2. Mediasi adalah intervensi dälam sebuah sengketa atău negosiasi oleh pihák ketiga yang bisa diterima pihak yang bersengketa, - bukan merupakan bagian dari kedua pihak dan bersifat netral. Pihak ketiga ini tidak mempunyai wewenang untuk mengambil keputusan. Dia bertugas untuk membantu pihak-pihak yang bertikai agar secara sukarela mau mencapai kata sepakat yang diterima oleh masingmasing pihak dalam sebuah persengketaan. ${ }^{18}$

3. Mediation is private, informal dispute resoIution process in which a neutral third person, the mediator, helps, disputing parties to reach an agreement. ${ }^{19}$

Peraturan Mahkamah Agung menyebutkan bahwa mediasi adalah penyelesaian sengketa melalui proses perundingan para pihak melalui mediator. Dari beberapa pengertian mediasi tersebut di atas dapat disimpulkan bahwa mediasi adalah upaya penyelesaian sengketa para pihak dengan kesepakatan bersama melalui mediator yang bersikap netral, dan tidak membuat keputusan atau kesimpulan bagi para pihak tetapi: menunjang fasilitator untuk terlaksananya dialog antar pihak-pihak dengan suasana keterbukaan, kejujuran, dan tukar pendapat untuk tercapainya mufakat. Dengan perkataan lain, proses mediasi pemecahan masalah adalah suatu proses di mana pihak luar yang tidak memihak (impartia) dan netral bekerja dengan pihak yang bersengketa untuk membantu mereka memperoleh kesepakatan perjanjian secara memuaskan. Berdasarkan pengertian mediasi tersebut, dapat disimpulkan beberapa karakteristik mediasi, yaitu:

${ }^{17}$ Gery Godpaster, Negosiasi dan Mediasi: Sebuah Pedoman Negosiasi dan Penyelesaian Sengketa Melalui Negosiasi (Jakarta: ELIPS Project, 1993), hlm 201.

${ }^{18}$ Christopher W. Moor, Mediasi Lingkungan (Jakarta: Indonesian Centre for Environmental Law dan ADR Associates, 1995), hlm 18.

${ }^{19}$ Henry Campbell Black, Black Law Dictionary, (StPaul Minn: West Publishing, 1990), hlm 981, dalam Gunawan Widjaja, op. cit., hlm 91. 
1. Penyelesaian sengketa sukarela (berdasar kesepakatan para pihak);.

2. Adanya intervensi atau bantuan pihak ketiga yang tidak berpihak atau netral;

3. Pengambilan keputusan oleh para pihak sendiri secara konsensus;

4. Partisipasi aktif pihak ketiga (mediator).

Untuk melihat keunggulan lembaga Mediasi, M. Yahya Harahap ${ }^{20}$ membandingkannya dengan lembaga Arbitrase dan proses Litigasi sebagai berikut:

Meskipun proses mediasi memiliki keunggulan atau keuntungan, tetapi tidak berarti sama sekali tidak ada kelemahannya. Sisi kelemahan dari proses mediasi ini antara lain mekanisme eksekusinya yang sulit karena hasil kesepakatan para pihak hanya mengikat sebagaimana perjanjian atau kontrak biasa, yang apabila kesepakatannya diingkari oleh salah satu pihak maka konsekuensinya dapat diajukan ke pengadilan melalui prosedur biasa (litigasi). Oleh karena itu mekanisme mediasi hasil keputusannya kurang memiliki wibawa. Disamping itu sangat digantungkan kepada itikad baik para pihak untuk menyelesaikan sengketanya sampai selesai, termasuk pelaksanaan atau realisasi kesepakatannya. Oleh karena itu untuk meminimalkan kelemahan tersebut kiranya diperlukan regulasi yang jelas lengkap yang mengatur institusi di luar pengadilan, termasuk mengatur prasyarat yang diperlukan. Kewibawaan putusan melalui proses mediasi akan berdampak pada meningkatnya kepercayaan masyarakat terhadap institusi mediasi ini. Dengan demikian akan menjadikan penggunaan mekanisme mediasi sebagai the first resort bahkan sekaligus the last resort.

Lembaga yang berperan dalam proses mediasi adalah lembaga-lembaga swadaya masyarakat yang secara parsial ikut berperan dalam proses mediasi, maupun lembaga lainnya yang didirikan sejak semula dengan kegiatan untuk menyelenggarakan atau menyediakan sarana' mediasi sebagai mekanisme penyelesaian sengketa di luar pengadilan baik dibentuk oleh pemerintah maupun swasta, misalnya:

1. Satuan Tugas Prakarsa Jakarta atau Jakarta Inisiative Task Force (JITF) dibentuk oleh pemerintah Indonesia atas pendanaan Bank Dunia tahun 1998. Satuan Tugas Prakarsa Jakarta ini berfungsi sebagai fasilitator antara debitur dan kreditur dalam penyelesaian utang swasta Indonesia kepada debitor asing (restrukturisasi utang perusahaan). Realisasi restrukturisasi utang perusahaan yang telah berhasil ditandatangani melalui mediasi JIFF hingga semester pertama tahun 2003 adalah 20,535 miliar dollar AS dari 96 perusahaan. Menjelang berakhimya tugas medio Desember 2003 JITF telah menyelesaikan $70 \%$ kasus-kasus utang piutang yang restrukturisasinya melalui mediasi; ${ }^{21}$

2. Pusat Mediasi Nasional (PMN) merupakan lembaga mediasi yang telah

${ }^{20}$ M. Yahya Harahap, "Alternative Dispute Resolution (ADR) Merupakan Jawaban Penyelesaian Sengketa Perdagangan Internasional Masa Depan", makalah Seminar Nasional Hukum Bisnis (Semarang: FH.UKSW, 1966).

${ }^{21} \mathrm{http} / /$ whw.kompas.com/brt/joe/8-8-2003, 28-11-2003. 
didirikan sejak Juni 2003 dan diresmikan oleh Ketua Mahkamah Agung tanggal 4 September 2003 setelah JITF yang didirikan atas pendanaan World Bank selesai beroperasi. PMN merupakan institusi swasta sebagai salah satu wadah untuk menyelesaikan sengketa di luar pengadilan. Lembaga ini bekerja sama dengan pemerintah dalam membantu menyelesaikan kasus-kasus restrukturisasi utang komersial yang tidak dapat diselesaikan baik oleh pemerintah maupun swasta, khususnya di pengadilan. Jangkauan mediasi tidak hanya mencakup sengketa komersial, tetapi sengketa lain (misalnya perburuhan, lingkungan, tehnik, industri) yang lebih luas daripada JITF. Salah satu peran yang diharapkan dari pembentukan PMN ini adalah memasyarakatkan mediasi sebagai suatu alternatif penyelesaian sengketa yang efektif dan tidak mahal. PMN juga mengembangkan kapasitas individu dengan menyelenggarakan pendidikan atau pelatihan mediasi sehingga tercipta mediator yang kompeten dan profesional. Khusus penyelesaian perselisihan di bidang lingkungan hidup, telah diatur dalam Peraturan Pemerintah Nomor 54 Tahun 2000 tentang Lembaga.Penyedia Jasa Pelayanan Penyelesaian Sengketa Lingkungan Hidup di luar Pengadilan sebagai pelaksanaan Undang-Undang Nomor 23 Tahung 1997 tentang Pengelolaan Lingkungan Hidup, dan Undang-Undang Nomor 30 Tahun 1999 tentang Arbitrase dan Altematif Penyelesaian Sengketa.
Pada prinsipnya peraturan pemerintah ini membuka kemungkinan dibentuknya lembaga penyedia jasa pelayanan penyelesaian sengketa lingkungan hidup di luar pengadilan oleh pihak pemerintah atau swasta dengan menggunakan mekanisme mediasi atau arbitrase. Lembaga penyedia jasa ini dapat didirikan dan beroperasi di seluruh wilayah Indonesia

\section{Institusionalisasi Mediasi dalam Sistem Peradilan}

Keluarnya Peraturan Mahkamah Agung Nomor 2 Tahun 2003 tentang Prosedur Mediasi di Pengadilan, berarti penyelesaian sengketa melalui institusi mediasi yang semula hanya dapat digunakan dalam penyelesaian berbagai konflik di luar pengadilan, sekarang terintegrasi ke dalam proses beracara di pengadilan. Dapat dikatakan bahwa pelembagaan proses mediasi dalam proses penyelesaian sengketa di pengadilan merupakan bentuk upaya konkrit deformalisasi hukum acara.

Upaya deformalisasi dalam hukum acara perdata sesungguhnya sudah sejak lama didengungkan. Pada bulan Agustus 1978 di Utrecth, Nederland oleh International Association for Procedural Law diselenggarakan konggres dalam rangka.8th Word Conference on. Procedural Law, yang bertemakan "Justic and Efficiency". Salah satu dari beberapa topik yang dibahas dalam konferensi tersebut adalah "Informal Alternatives to or Within Ordinary Litigation". ${ }^{n}$

22 Setiawan, Aneka Masalah Hukum dan Hukum Acara Perdata (Bandung: Alumni, 1992), hlm 362. 
Indonesia termasuk negara yang amat ketinggalan dalam merespon tuntutan masyarakat dunia untuk memanfaatkan mekanisme mediasi dalam sistem peradilannya. Di Singapore, dalam Subomdinate Rules 1966 terdapat ketentuan bahwa sebelum para pihak melanjutkan sengketanya ke pengadilan, terlebih dahulu ditempuh jalur antar pihak, sedang pelembagaan mediasi sebagai salah satu alternatif penyelesaian sengketa dilaksanakan pada Subordinate Court Singapore. Di Srilanka, mediasi merupakan upaya wajib yang harus ditempuh para justiciabel sebelum menempuh pengadilan (compulsory mediation atau primary jurisdiction). Sebagaimana halnya Srilanka, Pilipina juga menganut prinsip compulsory mediation. Gugatan ke pengadilan tidak dapat diajukan sebelum dinyatakan melalui sertifikat yang dikeluarkan oleh sekretaris panel konsiliasi (Lupong Tagapaya) bahwa upaya konsiliasi pemah dilakukan dan tidak membawa hasil. Sedangkan apabila tercapai kesepakatan, maka kesepakatan tersebut menjadi pengikat dan executable seperti halnya putusan pengadilan.

Pasal 130 HIR 154 Rbg. menentukan bahwa sebelum pokok materi sengketa diperiksa, maka hakim harus mengupayakan perdamaian kedua belah pihak yang berperkara. Implikasi ketentuan tersebut dalam praktek peradilan tidak efektif, hanya sebagai formalitas saja. Hakim hanya menganjurkan para pihak berdamai, tidak terlibat dalam proses damai. ${ }^{23}$
Pasal HIR 135a ayat 2 menentukan jika gugatan itu berhubung dengan perkara yang belum diputus hakim desa, sedang hakim memandang hal itu perlu maka pemeriksaan diundur sampai hari persidangan berikutnya. Alasan adanya ketentuan ini adalah agar pengadilan negeri memiliki pegangan dan pandangan tentang bagaimana hakim desa melihat perkara itu dari segi hukum adat. Putusan hakim desa dianggap sedemikian pentingnya, sehingga jika penggugat ternyata tidak membawa perkara tersebut kepada hakim desa setelah diperintahkan oleh Ketua Pengadilan Negeri, maka gugatannya dipandang tidak diteruskan. ${ }^{24}$ Nampaknya ketentuan ini sudah lama tidak diberlakukan lagi dalam praktek peradilan.

Hal tersebut dapat berpengaruh kepada masyarakat, bahwa upaya damai atas sengketa yang tejjadi oleh aparat hakim desa tidak diperlukan lagi melainkan langsung menempuh jalur pengadilan. Jadi pengadilam bagi mereka merupakan jalan yang terutama (the first resorf). Lembaga perdamaian dalam proses penyelesaian sengketa di pengadilan sangat tidak efektif. Hakim kurang berperan aktif dalam upaya perdamaian. Hal inilah yang antara lain melatarbelakangi keluamya SEMA Nomor 1 Tahun 2002 tentang Pemberdayaan Lemibaga Perdamaian, sebagaimana dimaksud dalam Pasal 130 HIR/154 Rbg.

Mendesaknya kebutuhan adanya lembaga mediasi di pengadilan didasarkan bahwa dari 16.000-an kasus kasasi dan Peninjauan Kembali yang masuk, ternyata

${ }^{23}$ Biasanya hakim menunda sidang pada sidang pertama untuk memberi kesempatan kepada kedua belah pihak untuk berdamai, jika pada sidang berikutnya tidak tercapai perdamaian, maka materi perkara langsung diperiksa

${ }^{24}$ R. Tresna, Komentar HIR (Jakarta: Pradnya Paramita, 1984), hlm 140. 
yang dapat diselesaikan oleh MA hanya sekitar 8.500-an perkara. ${ }^{25}$ Berdasarkan Pasal 79 Undang-Undang Nomor 14 Tahun 1985, Mahkamah Agung memiliki kewenangan untuk membuat regulasi mengenai hal-hal yang diperlukan bagi kelancaran penyelenggaraan peradilan apabila terdapat hal-hal yang belum cukup diatur dalam undang undang tegelende functie). Dengan demikian institusionalisasi proses mediasi dalam sistem peradilan diharapkan dapat memperkuat dan memaksimalkan fungsi lembaga pengadilan dalam membantu para justisiabel menyélesaikan sengketanya dan fungsi menegakkan hukum dan keadilan melalui kasus-kasus yang diajukan seseorang atau masyarakat disamping proses yang bersifat memutus (ajudikasi).

SEMA Nomor 1 Tahun 2002 tentang Pemberdayaan Lembaga Perdamaian mengatur petunjuk teknis atau operasional untuk memberdayakan upaya perdamaian agar efektif yaitu dengan 'menggunakan mekanisme mediasi. Prosedur mediasi dalam SEMA tersebut diambilalih dan disempurnakan lebih lanjut dalam PERMA Nomor. 2 Tahun 2003 tentang Prosedur Mediasi di Pengadilan sebagai upaya Mahkamah Agung untuk mengatasi kongesti (tunggakan perkara) derigan mènyediakan instrumen penyelesaian sengketa yang informal tetapi efektif dan tidak mahal. Dengan demikian menjadikan mekanisme mediasi terintegrasi dalam proses penyelesaian sengketa di pengadilan.

Beberapa ketentuan penting diatur dalam PERMA Nomor 2 Tahur 2003 menyangkut lembaga mediasi antara lain:

1. Kedudukan. Dalam sistem peradilan, lembaga mediasi merupakan bagian integral dari proses beracara di pengadilan. Semua perkara (perdata) yang diajukan ke pengadilan tingkat pertama wajib diselesaikan melalui proses mediasi. Implikasinya adalah para pihak yang bersengketa harus menempuh jalur perdamain terlebih dahulu melalui proses mediasi. Di pihak lain hakim yang memeriksa perkara yang bersangkutan, - secara ex officio wajib memerintahkan kepada para pihak untuk menyelesaikan sengketanya melalui mekanisme mediasi. Meskipun prosedur mediasi merupakan kewajiban tetapi ternyata kewajiban ini tidak bersanksi. Tidak ada ketentuan yang memberi sanksi apabila misalnya, hakim tidak memberi kesempatan kepada para pihak untuk mengupayakan perdamaian tersebut. ${ }^{26}$ Kewajiban yang bersanksi ini akan mendorong hakim dan masyarakat pencari keadilan untuk lebih mengutamakan solusi damai. Kiranya sanksi perlu diatur -sebagai penekan pendayagunaan mediasi. Barangkali perlu dicontoh sistem peradilan atau praktek mediasi pengadilan dari negara lain yang sudah mapan kelembagaannya.

\footnotetext{
${ }^{25}$ Suharto, Ketua Steering Commitee (SC) Draft Rancangan Peraturan Mahkamah Aging dalam seminar Rancangan Perma, Jakarta, 24 Juli 2003

${ }^{23}$ Bandingkan denigan Pasal 63 ayat (2).RUU Hukum. Acara Perdata hasil pembahasan Tim Antar Departemen dan Direktorat Perundang-undangan Departemen Kehakiman dan HAM Tahun 1995/1996, yang menentukan jika kewajiban mendamaikan tidak dilaksanakan maka keputusannya batal demi hukum.
} 
2. Fungsi dan Tujuan. Lembaga Mediasi berfungsi untuk menyediakan sarana bagi pihak-pihak yang bersengketa untuk mencari penyelesaian secara win-win solution berdasarkan kesepakatan. Segi praktis dari keberadaan lembaga mediasi bertujuan untuk memberdayakan perdamaian yang diatur dalam Pasal 130 HIR/154 Rbg.

3. Penunjukan mediator. Berdasarkan kesepakatan, para pihak yang bersengketa atau kuasa hukumnya dapat memilih mediator dari daftar mediator yang dimiliki pengadilan atau mediator di luar daftar pengadilan. Apabilatidak tejadikesepakatan tentang penggunaan mediator di dalam atau di luar daftar pengadilan, maka Ketua majelis hakim berwenang menunjuk mediator dari daftar mediator tingkat pengadilan pertama dengan suatu penetapan. Mediator pada setiap pengadilan berasal dari kalangan hakim dan bukan hakim, yaitu mereka yang telah memiliki sertifikat sebagai mediator. Hakim pemeriksa sengketa (ketua ataupun anggotanya) tidak dapat menjadi mediator - atas sengketa yang bersangkutan. Adapun kualifikasi mediator tidak ditentukan persyaratannya, hanya diharuskan memiliki sertifikat sebagai mediator. Mengingat mediator adalah profesi yang strategis untuk keberhasilan proses mediasi yaitu membantu mewujudkan tercapainya kesepakatan penyelesaian sengketa, maka untuk memperoleh sertifikat mediator harus diuji oleh orang atau lembaga yang memiliki kompetensi di bidang mediasi. Seharusnya instansi yang berwenang menguji dan mengeluarkan sertifikat juga harus ditentukan persyaratannya. Fungsi mediator antara lain membantu para pihak menyelesaikan sengketa, membingkai persoalan yang ada agar menjadi masalah yang perlu dihadapi bersama serta merumuskan perbagai pilihan penyelesaian sengketanya. ${ }^{27}$ Oleh karena itu mediator haruslah orang yang mempunyai pengetahuan luas (misalnya hukum ketenagakerjaan, lingkungan hidup, perbankan, dan bisnis), jujur, dapat dipercaya, punya integritas dan profesional. Merupakan suatu kenyataan bahwa salah satu kendala tidak efektifnya lembaga perdamaian di pengadilan adalah hakim-hakim tidak punya keahlian di bidang negosiasi/mediasi. Mereka terbiasa memutus sengketa dengan acara win-lose, tidak menempatkan diri sebagai penengah. Keberadaan mediator yang bukan dari kalangan hakim (menurut PERMA) tetapi profesional dapat membantu pengadilan mengatasi masalah penumpukan perkara dan kekurangan tenaga ahli mediasi di berbagai pengadilan di seluruh wilayah Indonesia.

4. Daya mengikat. Kesepakatan yang dicapai oleh para pihak melalui proses mediasi pengadilan, dapat dimintakan

${ }^{27}$ Pasal 9 ayat (4) PERMA Nomor 2 Tahun 2003 menyatakan mediator wajib mendorong para pihak untuk menelusuri dan menggali kepentingan mereka dan mencari berbagai pilihan penyelesaian sengketa yang terbaik bagi para pihak. 
penetapannya kepada hakim pemeriksa dalam suatu akta perdamaian yang lazim disebut acta van vergelijke. Ketentuan ini merupakan konsekuensi. logis dari pengintegrasian mediasi dalam proses penyelesaian sengketa di pengadilan. $\mathrm{Hal}$ ini merupakan salah satu keunggulan mediasi di pengadilan, mengingat ketentuan Pasal 130 HIR/154/ Rbg. memberi kekuatan terhadap penetapan perdamaian, seperti putusan biasa yang telah memperoleh kekuatan hukum tetap (inkracht van gewijsde), serta tidak dapat dibanding. Dengan demikian penyelesaian sengketa para pihak tuntas diselesaikan dalam tingkat peradilan pertama.

5. Cakupan materi sengketa meliputi sengketa keperdataan juga sengketa publik. Tidak dijelaskan lebih lanjut mengenai pengertian sengketa publik tersebut. Padahal hal ini penting, supaya implikasi dalam praktek tidak mengundang persoalan atau pertentangan pendapat ketika proses mediasi berlangsung. Dalam Pasal 1 butir 9 dan Pasal 14 PERMA tersebut hanya disebutkan jenis-jenis sengketa publik yang meliputi sengketa di bidang lingkungan hidup, hak asasi manusia, perlindungan konsumen, pertanahan dan perburuhan yang melibatkan kepentingan banyak buruh.

6. Kode etik. Secara tersirat PERMA mengharuskan adanya kode etik mediator. Kode etik mediator sangat penting, ia diperlukan khususnya untuk menjaga martabat dan kehormatan mediator itu sendiri.

7. Sifat persidangan dalam proses mediasi pada umumnya adalah tidak. bersifat terbuka untuk umum, kecuali pihak-pihak yang bersengketa menghendaki proses secara terbuka: Proses mediasi dalam sengketa publik bersifat terbuka karena menyangkut kepentingan orang banyak. Artinya, disamping para pihak dan atau kuasa hukumnya, maka wartawan dan orang lain dapat hadir menyaksikan, mendengar, mengikuti jalannya proses mediasi. Sifat tertutupnya suatu proses mediasi atau bentuk alternatif penyelesaian sengketa lainnya dan arbitrase sering dipilih justru karena sifatnya yang tertutup (prinsip confidentiality). Sifat tertutupnya proses, dimaksudkan untuk menjaga nama baik para pihak yang bersengketa, karena jika disebarluaskan maka akan dapat merugikan nama baik, kehormatan dan goodwill mereka dalam dunia bisnis dan hubungan sosial-ekonomi dalam masyarakat. Jadi persidangan yang tertutup bermaksud untuk melindungi kepentingan dagang pihak-pihak yang bersengketa.

8. Hukum Acara. Acara atau prosedur mediasi antara lain meliputi tahap-tahap mediasi, tenggang waktu, dan biaya medịasi.

\section{Mediasi dan Peradilan Cepat, Sederhan serta Murah}

Mediasi pengadilan sebagai proses penyelesaian sengketa melalui campur tangan pihak ketiga (mediator) selaku "penengah" memiliki keutamaan. Keutamaan tersebut dapat dilihat dari berbaga segi:

1. Segi yuridis, yaitu: 
a. Kesepakatan para pihak dapat dituangkan dalam penetapan hakim berupa akta perdamaian (acte van vergelijke), yang memiliki daya eksekutorial, karena diberi kekuatan hukum seperti putusan hakim biasa yang telah memperoleh kekuatan tetap sehingga memiliki wibawa;

b. Kesepakatan para pihak bersifat tuntas, karena tidak dapat diajukan upaya hukum biasa.

c. Kesepakatan yang dicapai para pihak dalam proses mediasi kecuali bermanfaat bagi pihak-pihak yang bersengketa sendiri sekaligus juga bagi terwujudnya peradilan yang cepat, sederhana dan murah.

2. Segi Sosial, meliputi:

a. Karena Kesepakatan yang dicapai didasarkan atas penyelesaian yang damai berdasar prinsip musyawarah mufakat yang mengutamakan win-win solution, maka dapat menjamin hubungan kemasyarakatan yang harmonis, hilangnya rasa permusuhan khususnya diantara para pihak, keluarganya dan juga masyarakat pada umumnya. Kedamaian, ketentraman dalam masyarakat dapat diwujudkan. Dibandingkan dengan putusan biasa, meskipun sengketa telah berakhir, tetapi hubungan kemasyarakatan diantara para pihak tetap ada ganjalan karena salah satu pihak merasa kecewa atas kekalahannya. b. Keberhasilan pendayagunaan mekanisme mediasi pengadilan juga akan menumbuhkan kepercayaan pada masyarakat khususnya justisiabel terhadap penegakan hukum oleh pengadilan.

3. 'Segi institusional. Bagi institusi pengadilan, terutama Mahkamah Agung, keberhasilan lembaga mediasi pengadilan dapat mengatasi menumpuknya perkara.

Efektifitas lembaga mediasi di pengadilan memerlukan partisipasi semua pihak yang terlibat dalam proses penegakan hukum, terutama hakim, karena dia-lah pemegang fungsi utama kehakiman. Hakim harus membantu para pencari keadilan dan berusaha sekeras-kerasnya mengatasi segala hambatan dan rintangan untuk dapat tercapainya peradilan yang sederhana, cepat dan biaya ringan sebagaimana diamaksud dalam Pasal 5 ayat (2) Undang-Undang Nomor 4 Tahun 2004 tentang Kekuasaan Kehakiman. Jadi Hakim harus aktif terutama dalam mengatasi hambatan dan rintangan untuk dapat tercapainya peradilan yang cepat (speedy administration of justice). Berlarutlarutnya atau tertundanya jalannya peradilan akan mengurangi kepercayaan masyarakat kepada pengadilan yang mengakibatkan berkurangnya kewibawaan pengadilan (justice delayed is justice denied). ${ }^{28}$

Pengadilan juga mempunyai fungsi pelayanan umum (public service). Bagaimanapun bunyi isi putusan pengadilan mengenai suatu konflik atau sengketa, tetapi kalau penyelesaiannya atau pemeriksaannya

${ }^{28}$ Sudikno Mertokusumo, Hukum Acara Perdata Indonesia (Yogyakarta: Liberty, 1998), hlm 91. 
cepat akan memberi ketentraman dalam masyarakat, maka akan menambah kewibawaan pengadilan atau pemerintah pada umumnya. Peradilan cepat menunjukkan pelayanan pemerintah yang baik terhadap rakyat yang membutuhkannya dan yang akan meningkatkan kepercayaan rakyat kepada pengadilan/pemerintah. Sebaliknya penyelesaian atau pemeriksaan oleh pengadilan yang berlarut-larut akan membuat justisiabel apatis dan segan untuk mengajukan perkaranya ke pengadilan. Pelayanan yang lamban akan mengurangi kepercayaan dan kewibawaan pemerintah.

\section{Simpulan}

Pelembagaan mediasi dalam pengadilan melalui bentuk Peraturan Mahkamah Agung kemungkinan kurang efektif, karena hakim dapat berpandangan lain yaitu menolak menggunakan prosedur mediasi dengan alasan bahwa. Peraturan Mahkamah Agung kedudukannya lebih rendah daripada undang-undang. Sedang perdamaian menurut ketentuan HIR/Rbg hanya bersifat fakultatif, artinya tidak merupakan kewajiban. ${ }^{29}$ Oleh karena itu PERMA perlu ditingkatkan dalam bentuk undang-undang.

Dalam hukum Acara Perdata mendatang proses mediasi itu harus dipertahankan. Sebelum ada undang-undangnya, PERMA harus disosialisasikan ke semua lingkungan pengadilan khususnya dalam kerangka untuk penyamaan persepsi. Pemerintah harus segera menyediakan sarana dan prasarana yang memadai demi terlaksananya lembaga mediasi sefara efektif.

\section{Daftar Pustaka}

Campbell Black, Henry, Black Law Dictionary, Saint Paul Minn: West Publishing, 1990

Emirzon, Joni, Alternatif Penyelesaian Sengketa di luar Pengadilan, Jakarta: SUN, 2000

- Engelbrecht. Himpunan Peraturan Perundang-undangan RI, Jakarta: Intermasa, 1989

Erawaty, Elly, dan J.S. Badudu, Kamus Hukum Ekonomi, Jakarta: ELIPs Project, 1997

Godpaster, Gery, Negosiasi dan Mediasi: Sebuah Pedoman Negosiasi dan Penyelesaian Sengketa Melalui Negosiasi, Jakarta: ELIPS Project, 1993

Harahap, M. Yahya, Beberapa Tinjauan mengenai Sistem Peradilan dan Penyelesaian Sengketa, Bandung: Citra Aditya Bakti, 1997

Harahap, Yahya, "Alternative Dispute Resolution (ADR), Merupakan Jawaban Penyelesaian Sengketa Perdagangan Internasional Masa Depan", Makalah pada Temu IImiah Nasional ISMAHI Implikasi Liberalisasi Perdagangan Intemasional terhadap Pembangunan Hukum Nasional, Jakarta: 1995

${ }^{28}$ Pasal 130 HIR/154 Rbg menetapkan Jika pada hari yang ditentukan kedua belah pihak datang maka Pengadilan Negeri mencoba dengan perantaraan ketuanya akan mendamaikan merekaitu. Lihat jugaEngelbrecht, Himpunan Perundang-undangan RI (Jakarta: Intermasa, 1989), hIm 717. 
Margono, Suyud, Altemative Dispute Resolution (ADR) dan Arbitrase, Jakarta: Ghalia Indonesia, 2000

Moor, Christopher W., Mediasi Linkungan, Jakarta: Indonesian Centre for Environmental Law dan ADR Associates, 1995

Pusat Pembinaan dan Pengembangan Bahasa, Kamus Besar Bahasa Indonesia, Jakarta: Departemen Pendidikan dan Kebudayaan

RUU Hukum Acara Perdata 1995/1996, Hasil Pembahasan Tim Antar Departemen dan Direktorat Perundang-undangan Departemen Kehakiman dan HAM

Samson, C., \& J. McBriede, Altemative Dispute Resolution, Les Presses de J'Universite Laval Sainte-Foy, 1993.

Santosa, Mas Achmad, Mekanisme Penyelesaian Sengketa Lingkungan Secara Kooperatif (Altemative Dispute Resolustion), Jakarta: Indonesian Centre for Enviromental Law, 1995

-__, Pendayagunaan Mekanisme Alternatif Penyelesaian Sengketa (MAPS) di Bidang Lingkungan di Indonesia, Jakarta: Indonesian Centre for Environmental Law, 1995 , "Alternative Dispute Resolution (ADR) di Bidang Lingkungan Hidup", disampaikan pada Forum Dialog tentang Altemative Dispute Resolution (ADR), Jakarta: Tim Pakar Hukum Departemen Kehakiman dan The Asia Fondation, 1995

Setiawan, Aneka Masalah Hukum dan Hukum Acara Perdata, Bandung: Alumni, 1992

Sutrisno, Nandang, "Penyelesaian Sengketa Bisnis di luar Pengadilan: ADR sebagai Pilihan", makalah Diskusi ADR, Yogyakarta: Fakultas Hukum Universitas Islam Indonesia

Tresna, R., Komentar HIR, Jakarta: Pradnya Paramita, 1984

Usman, Rachmadi, Pilihan Penyelesaian Sengketa di luar Pengadilan, Bandung: Citra Aditya Bakti, 2003

Wijaya, Gunawan, Alternatif Penyelesaian sengketa, Jakarta: Raja Grafindo Persada, 2001

\section{Website}

http://www.hukumonline.com/brt/cr-1/ 4Juni2004

http://www.kompas.com/brt/dwa/16-3-2004

http://www.kompas.com/ima/10-6-2004/13:45

http://www.hukumonline:com/leo/gie, 23-62004/20:15 